\title{
Interleukin-26 is a promising biomarker of sepsis but is it always reliable?
}

\author{
Patrick M. Honore*, Aude Mugisha, Leonel Barreto Gutierrez, Sebastien Redant, Keitiane Kaefer, \\ Andrea Gallerani and David De Bels
}

We read with interest the recent article by $\mathrm{Tu}$ et al. concluding that interleukin-26 (IL-26) is a better predictor of 28-day mortality in septic patients when compared with $\mathrm{C}$-reactive protein (CRP) and procalcitonin (PCT) [1]. However, SOFA score remains the best predictor by far over IL-26. While we applaud the results of this study, we would like to make some comments. IL-26 is the most recently identified member of the IL20 cytokine subfamily and is a promising mediator of inflammation overexpressed in activated or transformed $\mathrm{T}$ cells [2]. IL-26 has a molecular weight ranging between 19 and $36 \mathrm{kDa}$. Nearly half of critically ill patients especially those with septic shock have or develop acute kidney injury (AKI), and $20-25 \%$ will need renal replacement therapy (RRT) within the first week of their stay [3]. Out of the 52 septic patients in this study, several patients will develop AKI and necessitate continuous RRT (CRRT) [1]. The serum for IL-26 was taken on admission in the intensive care unit (ICU) in this study, and nothing can be said about the reliability of the admission level. Nevertheless, we would like to warn the clinician about daily monitoring of IL-26 like for CRP and PCT. CRRT is performed using membranes that have a cutoff value of $35-40 \mathrm{kDa}$, and therefore, some quantity of IL-26 will be eliminated by CRRT [4]. New highly adsorptive membranes (HAM) that can adsorb many molecules with a molecular weight above $35 \mathrm{kDa}$ will even increase this removal [5]. This can mislead patient prognostication by artificially decreasing IL-26, but no studies have challenged this issue yet. Such studies should be done as there is already a long list of biomarkers in sepsis that are lacking reliability during CRRT [5]. To date, no single sepsis biomarker can be reliable during CRRT. While

\footnotetext{
* Correspondence: Patrick.Honore@CHU-Brugmann.be

This comment refers to the article available at https://doi.org/10.1186/ s13054-019-2574-7.

ICU Department, Centre Hospitalier Universitaire Brugmann, Place Van Gehuchtenplein, 4, 1020 Brussels, Belgium
}

admission levels of IL-26 might be a good marker of severity and mortality of sepsis, this might not be the case for septic shock under CRRT $[4,5]$.

\section{Abbreviations \\ IL-26: Interleukin-26; CRP: C-reactive protein; PCT: Procalcitonin; AKI: Acute kidney injury; RRT: Renal replacement therapy; CRRT: Continuous renal replacement therapy; HAM: Highly adsorptive membranes}

\section{Acknowledgements}

None.

\section{Authors' contributions}

$\mathrm{PMH}$ and DDB designed the paper. All authors participated in drafting and reviewing. All authors read and approved the final version of the manuscript.

\section{Funding}

None.

Availability of data and materials

Not applicable.

Ethics approval and consent to participate

Not applicable.

\section{Consent for publication}

Not applicable.

\section{Competing interests}

The authors declare that they have no competing interests.

Received: 26 September 2019 Accepted: 29 November 2019

Published online: 06 December 2019

References

1. Tu H, Lai X, Li J, Huang L, Liu Y, Cao J. Interleukin-26 is overexpressed in human sepsis and contributes to inflammation, organ injury, and mortality in murine sepsis. Crit Care. 2019;23(1):290. https://doi.org/10.1186/s13054019-2574-7.

2. Larochette V, Miot C, Poli C, Beaumont E, Roingeard P, Fickenscher H, et al. IL-26, a cytokine with roles in extracellular DNA-induced inflammation and microbial defense. Front Immunol. 2019;10:204. https://doi.org/10.3389/ fimmu.2019.00204 eCollection 2019.

3. Peters E, Antonelli M, Wittebole X, Nanchal R, François B, Sakr Y, et al. A worldwide multicentre evaluation of the influence of deterioration or improvement of acute kidney injury on clinical outcome in critically ill patients with and without sepsis at ICU admission: results from The Intensive Care Over Nations audit. Crit Care. 2018;22(1):188. https://doi.org/ 10.1186/s13054-018-2112-z.

4. Honoré PM, Jacobs R, De Waele E, Van Gorp V, Spapen HD. Evaluating sepsis during continuous dialysis: are biomarkers still valid? Blood Purif. 2014;38(2):104-5. https://doi.org/10.1159/000363497 Epub 2014 Oct 17. 
5. Honoré PM, De Bels D, Spapen HD. An update on membranes and cartridges for extracorporeal blood purification in sepsis and septic shock. Curr Opin Crit Care. 2018;24(6):463-8. https://doi.org/10.1097/MCC. 0000000000000542 Review.

\section{Publisher's Note}

Springer Nature remains neutral with regard to jurisdictional claims in published maps and institutional affiliations. 